\title{
Using filtrate of waste biosolids to effectively produce bio-hydrogen by anaerobic fermentation
}

\author{
C.C. Wang ${ }^{\mathrm{a}}$, C.W. Chang ${ }^{\mathrm{a}}$, C.P. Chu ${ }^{\mathrm{a}}$, D.J. Lee ${ }^{\mathrm{a}, *}$, Bea-Ven Chang ${ }^{\mathrm{b}}$, \\ C.S. Liao ${ }^{\mathrm{b}}$, J.H. Tay ${ }^{\mathrm{c}}$ \\ ${ }^{a}$ Department of Chemical Engineering, National Taiwan University, Taipei 10617, Taiwan \\ ${ }^{\mathrm{b}}$ Department of Microbiology, Soochow University, Taipei 111, Taiwan \\ ${ }^{\mathrm{c}}$ Division of Environmental and Water Resource Engineering, School of Civil and Environmental Engineering, \\ Nanyang Technological University, Singapore 639798, Singapore
}

Received 20 August 2002; received in revised form 3 December 2002; accepted 12 December 2002

\begin{abstract}
Waste biosolids collected from sewage works is a biomass containing a vast amount of polysaccharides and proteins, and thus is considered a potential substrate for producing hydrogen using anaerobic fermentation. This work demonstrated, contrary to the common assumption, that the solids phase in waste activated biosolids presents extra nutrients for anaerobes; it in fact prohibits effective bio-hydrogen production. Using filtrate after removal of solids from biosolids produces more hydrogen than using the whole biosolids, with the former reaching a level an order of magnitude higher than the literature results.
\end{abstract}

(C) 2003 Elsevier Science Ltd. All rights reserved.

Keywords: Hydrogen; Biosolids; Fermentation; Filtrate; Yield

\section{Introduction}

Hydrogen is a clean energy source. Bio-conversion of biomass to hydrogen production is technically feasible using anaerobic fermentation [1]. Bio-hydrogen has been produced from high-strength wastewater [2-4], solids waste [5,6], or certain substances in water, like molasses [7], glucose [8,9], crystalline cellulose [10], peptone [11], and starch [12]. Ways to enhance hydrogen production were reported [13-17]. During anaerobic digestion methanogenic or sulfate reducing bacteria could consume hydrogen produced by acidogenic bacteria, thereby is negative to bio-hydrogen production [18].

Waste biomass collected from the activated sludge process of wastewater treatment plant contains high level of organic matter, and thus is a potential substrate for hydrogen production. Only limited data are avail-

\footnotetext{
*Corresponding author. Fax: + 886-2-2362-3040.

E-mail address: djlee@ccms.ntu.edu.tw (D.J. Lee).
}

able considering waste biosolids as the substrate to fermentation. Huang et al. [19] revealed a very low yield, ca. $0.16 \mathrm{mg} \mathrm{H}_{2} / \mathrm{g}$ dried solids, from waste biosolids produced in a municipal sewage works. Cheng et al. [20] thermally boiled the waste biosolids to release the insoluble organic matter from the solids phase, and noted in the subsequent anaerobic fermentation test a yield of $1.4 \mathrm{mg} \mathrm{H}_{2} / \mathrm{g}$ COD. This value is comparable to that for protein fermentation, but is still far lower than that for polysaccharides. The very low hydrogen yield discourages the use of waste biosolids as the fermentation substrate.

With a Clostridium strain purified from collected waste biosolids as seed bacteria, we demonstrated in this work that not only the solids phase in the waste biosolids could not be utilized by the anaerobes as nutrient, but also it effectively reduced the hydrogen production. Fermentation of filtrate rather than of the whole biosolids could produce a high bio-hydrogen yield comparable to that for glucose. 


\section{Experimental}

\subsection{The substrate}

Waste biosolids was taken from the Min-Sheng Municipal Wastewater Treatment Plant in Taipei, which handles 15,500tons sewage per day using primary, secondary, and tertiary treatment stages. Two samples were collected at the recycle stream of activated sludge process on March 14 and on April 23, 2002, respectively, namely the samples 1 and 2 in this work. The sample 1 was collected at normal operational condition, while the sample 2 was collected at a condition that the Plant had been shut down for a week at nutrient-insufficient stage that consisted of less digestible matters compared with the sample 1 . The collected samples were gravitationally settled for $24 \mathrm{~h}$ and the sediments were stored at $5^{\circ} \mathrm{C}$. Then the filtrate was obtained from vacuum filtering the biosolids sample through a Whatman 2 paper. Both the whole biosolids and their filtrates were the substrates in the fermentation tests. Table 1 lists their characteristics. The chemical oxygen demands (COD) for the biosolids were much higher than those for the filtrate, indicating that most organic compounds in the biosolids sample were in an insoluble form.

\subsection{The inoculum}

The inoculum was prepared from the original biosolids using the following procedures. Firstly, the methanogenic bacteria in the collected biosolids were pasteurized at $121^{\circ} \mathrm{C}$ and $1.2 \mathrm{kgf} / \mathrm{cm}^{2}$ (HUXLEY AUTOCLAVE, HL-360) in an anaerobic chamber for $30 \mathrm{~min}$ [12]. This action would sterilize most microorganisms. However, the subsequent incubation stage revealed that certain heat-resistance bacteria could survive and were hence isolated. Then $100 \mathrm{mM}$ of methanogenic bacterial inhibitor, BESA $\left(\mathrm{C}_{2} \mathrm{H}_{4} \mathrm{BrO}_{3} \mathrm{SNa}\right.$, Sodium 2-Bromoethanesulfonate, Sigma, USA), was added to the pasteurized biosolids. After incubation the dosed biosolids was spread on a gel-type reinforced clostridial medium (OXOID) and colonized for 3 days.

Table 1

Sample characteristics

\begin{tabular}{llllll}
\hline Properties & \multicolumn{2}{c}{ Sample 1} & & & \multicolumn{2}{c}{ Sample 2 } & \\
\cline { 2 - 3 } \cline { 5 - 6 } \cline { 5 - 6 } & Sediment & Filtrate & & Sediment & Filtrate \\
\hline Solids content $(\mathrm{mg} / \mathrm{L})$ & 16,500 & $\mathrm{NA}^{\mathrm{a}}$ & & 15,000 & $\mathrm{NA}$ \\
$\mathrm{pH}$ & 6.4 & 6.9 & & 6.2 & 6.7 \\
$\mathrm{COD}(\mathrm{mg} / \mathrm{L})$ & 24,800 & 436 & & 24,400 & 510 \\
Zeta potential $(\mathrm{mV})$ & -19.1 & -21.9 & & -20.1 & -26.9 \\
Floc size $(\mu \mathrm{m})$ & 71.6 & $\mathrm{NA}$ & 47.6 & $\mathrm{NA}$ \\
\hline
\end{tabular}

${ }^{\mathrm{a}}$ Not available.

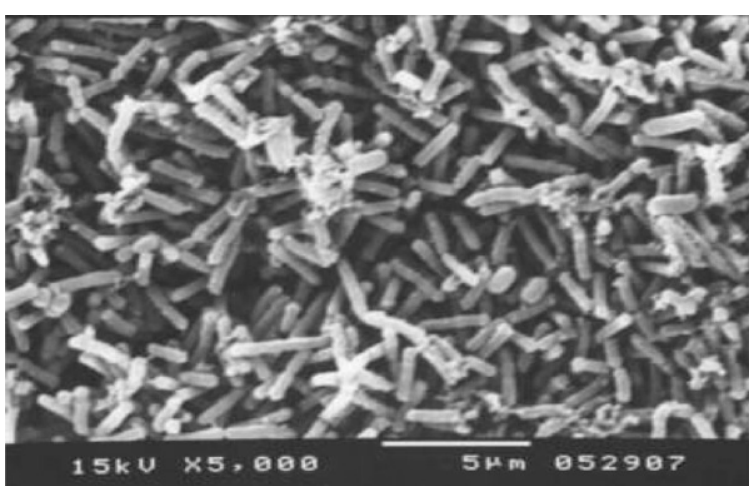

Fig. 1. Scanning electron microscopy (SEM) photograph for the Clostridium sp. identified in this test.

Individual colonies were removed from the medium and incubated on the agar for strain purification. After three-time purification 10 colonies of anaerobes were picked up and incubated in liqueur reinforced clostridial medium. These strains were seeded into pasteurized biosolids at anaerobic fermentor. Four strains with the highest hydrogen productivity were mixed and stored as the inoculum in the fermentation tests. Polymerase chain reaction followed by $16 \mathrm{~S}$ DNA sequencing technique revealed that these anaerobes belong to the clostridia family (detail in Ref. [21]). Fig. 1 demonstrates the SEM photograph of the isolated strain.

\subsection{Fermentation and tests}

Forty-five milliliter of substrate (biosolids or their filtrates) was mixed with $5-\mathrm{ml}$ seed bacteria suspension and was anaerobically incubated at $35^{\circ} \mathrm{C}$ in $125-\mathrm{ml}$ serum bottles without stirring or further nutrient addition. The bottles were capped with butyl rubber stoppers and wrapped by aluminum foils to prevent possible photolysis reaction of the substrate [22]. Gas and liquor samples were collected at 8, 16, 24, 32, 40, 48, 72 , and $96 \mathrm{~h}$ of fermentation, at each time interval and for each substrate three serum bottles were randomly chosen. Restated, under identical condition three incubated samples were measured and their average was reported. After measurements these samples were abandoned to prevent any possible errors introduced by sampling procedures, such as gas leakage during sampling. The substrate had not been sterilized before tests. Control tests with substrate but without dosing of inoculum revealed negligible hydrogen production (less than $20 \%$ of the one with clostridium dosing). Hence, the hydrogen-producing species in the original biosolids played no significant role in the present test.

GC-TCD (Shimadzu, GC-8A), equipped with a stainless column packed with Porapack Q (50/80 mesh) 


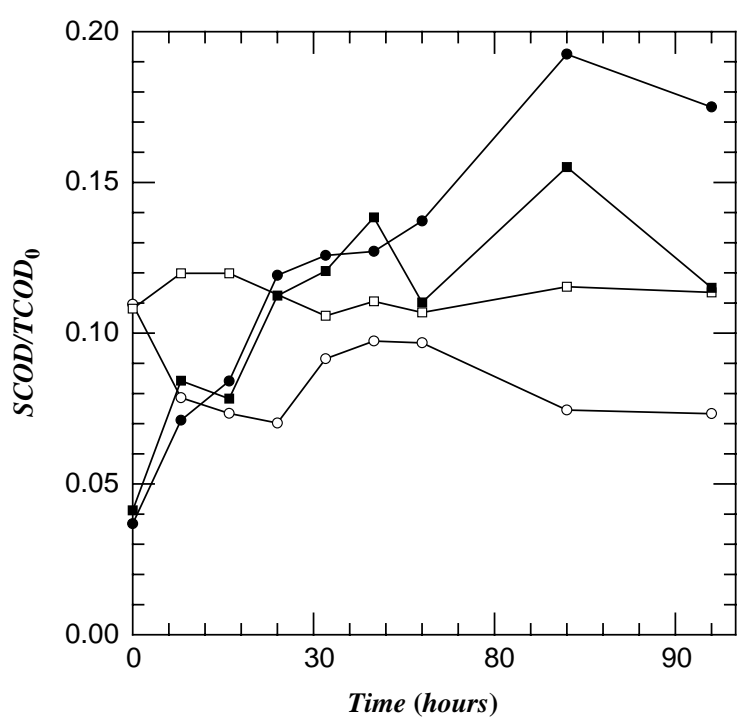

Fig. 2. The $\mathrm{COD} / \mathrm{TCOD}_{0}$ of whole biosolids and filtrate tests. Solid circle: the soluble COD of biosolids sample 1; Solid square: the soluble COD of biosolids sample 2; Open circle: total COD of the filtrate test 1; Open square: total COD of the filtrate test 2 .

at $70^{\circ} \mathrm{C}$ and thermal-conductivity detector (TCD), measured the methane and hydrogen concentrations in gas phase. The temperatures of injector and of detector of GC were at $100^{\circ} \mathrm{C}$. Nitrogen at a flow rate of $20 \mathrm{ml} /$ min was the carrying gas. Integrator (HP3396 Series II) was used to integrate the peak area of the effluent curve, and hence quantifying the gaseous concentrations. The hydrogen content in the anaerobic glove box was measured as well, and was subtracted from the hydrogen concentrations in the serum bottles.

\section{Results and discussion}

\subsection{Hydrolysis of organic matter}

Fig. 2 depicts the COD data of filtrate of fermented biosolids samples and those for filtrate samples. These data are normalized by the COD for the original biosolids, $\mathrm{COD}_{0}(=24,800 \mathrm{mg} / \mathrm{l}$ for sample 1 , for instance). Although some data scattering existed, two points are worthy noticing. Firstly, the soluble COD for the original biosolids comprises of only $4 \%$ of $\mathrm{COD}_{0}$. During fermentation the soluble COD for the whole biosolids samples increase to $8-16 \%$. Hydrolysis of solids phase occurred in the fermented biosolids samples. For the filtrate test, on the other hand, the total COD of the suspension initially comprises of $11 \%$ of $\mathrm{COD}_{0}$, indicating the large contribution of the seed bacteria. The COD fluctuates with time but did not reveal an increasing trend. Most substances in biosolids

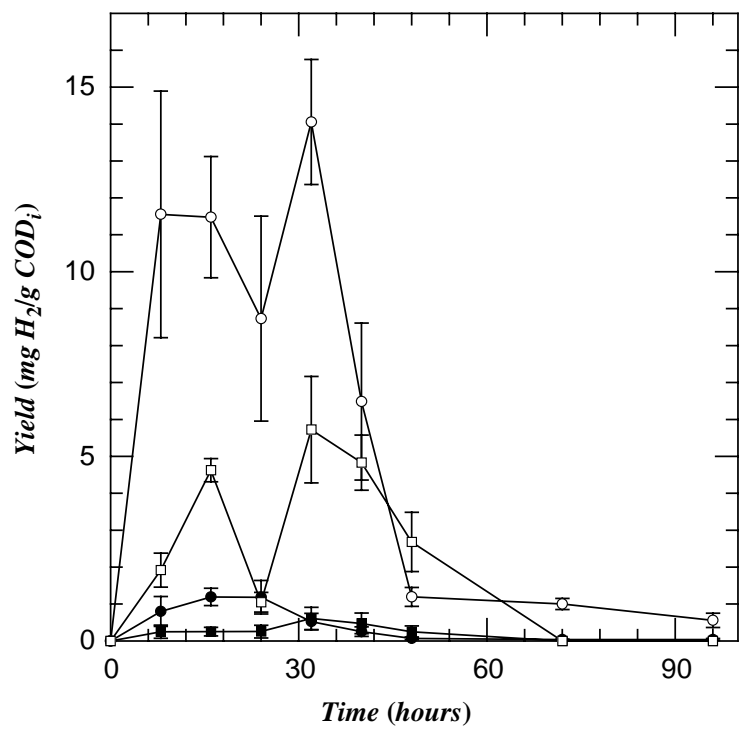

Fig. 3. The hydrogen yield of sludge and filtrate tests. Solid circle: the biosolids sample 1; Solid square: the biosolids sample 2; Open circle: the filtrate test 1; Open square: the filtrate test 2.

sample ready to hydrolyze has been removed by the filter during vacuum filtration. Seed bacteria contributed to the initial COD in filtrate test but did not further affect its value in subsequent tests.

\subsection{Hydrogen production}

Fig. 3 depicts the specific hydrogen yield based on unit gram of COD $\left(\mathrm{mg} \mathrm{H}_{2} / \mathrm{g} \mathrm{COD}_{i}\right)$, where $\mathrm{COD}_{i}$ is the COD for the substrate before testing (that is, the seed bacteria + biosolids, or seed bacteria + filtrate before the fermentation test). Some authors reported their hydrogen yields based on COD consumption $[5,15]$. This expression is particularly useful for continuous fermentation test. However, since the microbial community evolves, and the hydrolysis of organic matters occurs over the batch test, COD measurements fluctuate, as Fig. 2 reveals. In fact, the COD was not "consumed" but "accumulated" with time. We hence summarized the hydrogen yield based on initial COD reading which represents a more relevant index for batch fermentation test. In addition, as discussed later, this index provides information on the fraction of COD that is readily fermented to hydrogen.

The hydrogen concentration in the gas-phase presents an increasing-decreasing curve, with its peak occurring at around $16-30 \mathrm{~h}$. This occurrence is noticeable for both biosolids and the filtrate tests, indicating that certain amount of produced hydrogen is later in some way "consumed". Cheng et al. [20] reported a similar "hydrogen-consumption" phase during anaerobic fermentation. 
As Fig. 3 reveals, the specific hydrogen yield could reach 1.2 or $0.6 \mathrm{mg} / \mathrm{g} \mathrm{COD}_{i}$ for the biosolids sample 1 or 2, equivalent to 1.8 or $0.9 \mathrm{mg} / \mathrm{g}$ dried biosolids, respectively. This level is much higher than that reported by Huang et al. [19] $\left(0.16 \mathrm{mg} \mathrm{H}_{2} / \mathrm{g}\right.$ dried biosolids). Moreover, based on unit mass of COD, the filtrate could produce hydrogen to a level of $10-15 \mathrm{mg} \mathrm{H}_{2} / \mathrm{g} \mathrm{COD}$, approximately 10 times to the literature results $(1.4 \mathrm{mg}$ $\mathrm{H}_{2} / \mathrm{g}$ COD). This yield is much higher than that for protein and is close to that for glucose.

Hypothetical tests were conducted for comparing the average hydrogen yield of biosolids. Two hypotheses, $M_{\mathrm{F}}>M_{\mathrm{O}}$ (hydrogen yield for the filtrate test is higher than that for the whole biosolids) or $M_{\mathrm{F}} \neq M_{\mathrm{O}}$ (hydrogen yield for the filtrate test is not equal to that for the whole biosolids) were tested, which could be accepted at a confidence level of $1-\alpha$ if

$$
\begin{gathered}
H_{>}=\frac{\left|\bar{X}_{\mathrm{F}}-\bar{X}_{\mathrm{O}}\right|}{t_{1-\alpha} s_{\mathrm{p}}\left(\frac{1}{n_{\mathrm{F}}}+\frac{1}{n_{\mathrm{O}}}\right)^{1 / 2}}>1 \text { or } \\
H_{\neq}=\frac{\left|\bar{X}_{\mathrm{F}}-\bar{X}_{\mathrm{O}}\right|}{t_{1-0.5} s_{\mathrm{p}}\left(\frac{1}{n_{\mathrm{F}}}+\frac{1}{n_{\mathrm{O}}}\right)^{1 / 2}}>1,
\end{gathered}
$$

respectively [23]. Where $\bar{X}, s$, and $n$ are the mean value, standard deviation, and data number, respectively, while $t_{1-0.5 \alpha}$ and $t_{1-\alpha}$ were the corresponding values of $t$-distribution in $(1-0.5 \alpha)$ and $(1-\alpha)$ with the degree of freedom $\left(n_{\mathrm{F}}+n_{\mathrm{O}}-2\right)$.

The hypothetical test in Table 2 reveals that the filtrate could produce more hydrogen than the whole biosolids at a confidence of interval of $95 \%$. And thus, the solids phase in the suspension could not be used as the substrate by anaerobes during fermentation, but on the contrary have a negative impact on the hydrogen productivity.

\section{Discussion}

The role of solids phase on hydrogen yield might be attributable to several reasons. For instance, the highly concentrated substrate might be inhibitive to the acidogenic bacteria. However, this proposal cannot interpret the observed hydrogen-consuming phase in Fig. 3. The solids phase might absorb certain products or deliver toxic substances during fermentation. Further, the methanogenic bacteria might exist together with the solids phase, which had converted the formed hydrogen to methane. Fig. 4 depicts the accumulated methane in the serum bottles. Methane was observed for tests of both biosolids samples, but was not noted at filtrate tests. The methane production amount for biosolids sample 1 on day 4 is only $2.95 \mathrm{mg} / \mathrm{g}$ COD $(4.4 \mathrm{~g} / \mathrm{kg}$ dried solids), much lower than that reported by Chu et al. [24]
Table 2

\begin{tabular}{|c|c|c|c|c|c|c|}
\hline \multicolumn{7}{|c|}{ Sample 1} \\
\hline \multirow[t]{2}{*}{ Hour } & \multicolumn{2}{|c|}{ Sludge } & \multicolumn{2}{|c|}{ Filtrate } & \multirow[t]{2}{*}{$H_{>}$} & \multirow[t]{2}{*}{$H_{\neq}$} \\
\hline & $\bar{X}_{\mathrm{O}}$ & $s_{\mathrm{O}}$ & $\bar{X}_{\mathrm{F}}$ & $s_{\mathrm{F}}$ & & \\
\hline 8 & 0.8 & 0.4 & 11.56 & 3.34 & 1.90 & 1.29 \\
\hline 16 & 1.2 & 0.2 & 11.48 & 1.64 & 3.68 & 2.50 \\
\hline 24 & 1.2 & 0.5 & 8.73 & 2.77 & 1.59 & 1.08 \\
\hline 32 & 0.5 & 0.2 & 14.05 & 1.69 & 4.70 & 3.19 \\
\hline 40 & 0.3 & 0.1 & 6.49 & 2.13 & 1.74 & 1.18 \\
\hline 48 & 0.1 & 0.0 & 1.19 & 0.26 & 2.56 & 1.73 \\
\hline 72 & 0.0 & 0.0 & 1.00 & 0.15 & 3.76 & 2.55 \\
\hline 96 & 0.0 & 0.0 & 0.56 & 0.19 & 1.57 & 1.06 \\
\hline \multicolumn{7}{|c|}{ Sample 2} \\
\hline 8 & 0.3 & 0.2 & 1.92 & 0.46 & 2.01 & 1.36 \\
\hline 16 & 0.3 & 0.1 & 4.62 & 0.31 & 7.77 & 5.27 \\
\hline 24 & 0.3 & 0.2 & 1.05 & 0.27 & 1.49 & 1.01 \\
\hline 32 & 0.6 & 0.3 & 5.72 & 1.44 & 2.06 & 1.40 \\
\hline 40 & 0.5 & 0.3 & 4.83 & 0.75 & 3.23 & 2.19 \\
\hline 48 & 0.3 & 0.2 & 2.68 & 0.80 & 1.76 & 1.20 \\
\hline 72 & 0.0 & 0.0 & 0 & 0 & NA & NA \\
\hline 96 & 0.0 & 0.0 & 0 & 0 & NA & NA \\
\hline
\end{tabular}

Hypothetical tests

$H_{>}>1$ or $H_{\neq}>1$ indicate that the hypotheses "hydrogen yield for filtrate test is higher than that for whole biosolids test" or "hydrogen yield for filtrate test is not equal to that for whole biosolids test" are accepted at a confidence level of $95 \%$.

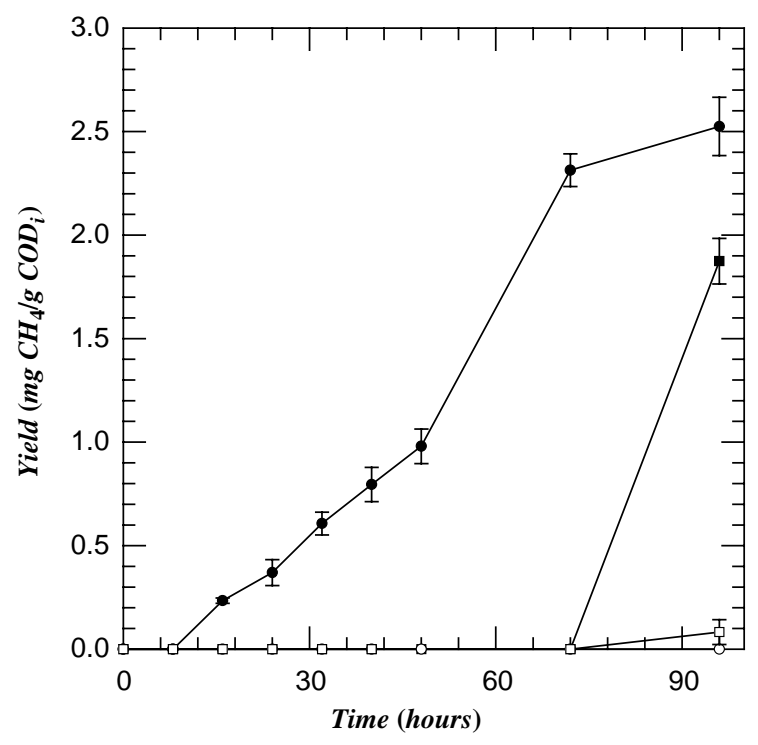

Fig. 4. The methane yield of sludge and filtrate tests. Solid circle: the biosolids sample 1; Solid square: the biosolids sample 2; Open circle: the filtrate test 1; Open square: the filtrate test 2.

(ca. $25 \mathrm{~g} / \mathrm{kg}$ dried solids) in which the methanogenic bacteria was externally dosed at time zero. In addition, the methane was yielded by sample 2 only after $72-\mathrm{h}$ 
fermentation. Hence, The methane production could not interpret the complete exhaust of hydrogen observed in the fermentation tests.

Although the underlying mechanisms remain unclear, the use of filtrate is superior to that of the whole biosolids to anaerobic bio-hydrogen fermentation. Separating and fermenting filtrate from the biosolids is a preferable scheme for $\mathrm{H}_{2}$ formation. Pre-treatment has been adopted for releasing insoluble organic matters into water, thereby enhancing the efficiency of anaerobic digestion process for methane production [25]. The soluble COD kept increasing in the biosolids test (Fig. 2), which did not correlate with the observed trend for hydrogen yield. Therefore, not all dissolved organic matters could be converted into hydrogen. The feasibility of using pre-treatment process before hydrogen production should be carefully examined. More works are now under going for detailed investigation to this hydrogen production process.

\section{References}

[1] Miyake J, Miyake M, Asada Y. Biotechnological hydrogen production: research for efficient light energy conversion. J Biotechnol 1999;70:89-101.

[2] Liu SJ, Yang WF, Zhou PQ. The research on hydrogen production from the treatment of bean products wastewater by immobilized photosynthetic bacteria. Environ Sci 1995; 16:42-4.

[3] Ueno Y, Otauka S, Morimoto M. Hydrogen production from industrial wastewater by anaerobic microflora in chemostat culture. J Ferment Bioeng 1996;82:194-7.

[4] Zhu H, Suzuki T, Tsygankov AA, Asada Y, Miyake J. Hydrogen production from tofu wastewater by Rhodobacter sphaerodies immobilized in agar gels. Int $\mathbf{J}$ Hydrogen Energy 1999;24:305-10.

[5] Mizuno O, Ohara T, Shinya M, Noike T. Characteristics of hydrogen production from bean curd manufacturing waste by anaerobic microflora. Water Sci Technol 2000;42(3-4):345-50.

[6] Lay JJ, Lee YJ, Noike T. Feasibility of biological hydrogen production from organic fraction of municipal solid waste. Water Res 1999;33:2579-86.

[7] Tanisho S, Ishiwata Y. Continuous hydrogen production from molasses by the bacterium Enterobacter aerogenes. Int J Hydrogen Energy 1994;19:807-12.

[8] Kataoka N, Miya A, Kiriyama K. Studies on hydrogen production by continuous culture system of hydrogenproducing anaerobic bacteria. Water Sci Technol 1997;36(6-7):41-7.
[9] Lin CY, Chang RC. Hydrogen production during the anaerobic acidogenic conversion of glucose. J Chem Technol Biotechnol 1999;74:498-500.

[10] Lay JJ. Biohydrogen generation by mesophilic anaerobic fermentation of microcrystalline cellulose. Biotechnol Bioeng 2001;74:280-7.

[11] Bai MD, Cheng SS, Tseng IC. Biohydrogen produced due to peptone degradation by pretreated seed sludge. The IWA Asia-Pacific Regional Conference, Asian WATERQUAL 2001, Fukuoka, Japan, 2001.

[12] Lay JJ. Modeling and optimization of anaerobic digested sludge converting starch to hydrogen. Biotechnol Bioeng 2000;68:269-78.

[13] Tanisho S, Ishiwata Y. Continuous hydrogen production from molasses by fermentation using urethane foam as a support of flocks. Int J Hydrogen Energy 1995;20:541-5.

[14] Tanisho S, Kuromoto M, Kadokura N. Effect of $\mathrm{CO}_{2}$ removal on hydrogen production by fermentation. Int $\mathrm{J}$ Hydrogen Energy 1998;23:559-63.

[15] Mizuno O, Dinsdale R, Hawkes FR, Hawkes DL, Noike $\mathrm{T}$. Enhancement of hydrogen production from glucose by nitrogen gas sparging. Bioresource Technol 2000;73:59-65.

[16] Sparling R, Risbey D, Poggi-Varaldo HM. Hydrogen production from inhibited anaerobic composters. Int $\mathbf{J}$ Hydrogen Energy 1997;22:563-6.

[17] Liang TM, Wu KL, Cheng SS. Hydrogen production of chloroform inhibited granular sludge. The IWA AsiaPacific Regional Conference, Asian WATERQUAL 2001, Fukuoka, Japan, 2001.

[18] Adams MWW, Stiefel EI. Biological hydrogen production: not so elementary. Science 1998;282:1842-3.

[19] Huang CH, Lin HY, Tsai YY, Hsie YK. The preliminary studies of hydrogen production from anaerobic digestion with different substrates and cultivations. The 25th Wastewater Technology Conference, Yunlin, Taiwan, 2000 (in Chinese).

[20] Cheng SS, Bai MD, Chang SM, Wu KL, Chen WC, Chen WC. Studies on the feasibility of hydrogen production hydrolyzed sludge by anaerobic microorganisms. The 25th Wastewater Technology Conference, Yunlin, Taiwan, 2000 (in Chinese).

[21] Wang CC. Producing hydrogen from wastewater sludge. MS thesis, National Taiwan University, Taipei, Taiwan, 2002.

[22] Chang BV, Zheng JX, Yuan SY. Effects of alternative electron donors, acceptors and inhibitors on PCP dechlorination in soil. Chemosphere 1996;33:313-20.

[23] Himmelblau DM. Process analysis by statistical methods. New York: Wiley, 1970. p. 61-4.

[24] Chu CP, Lee DJ, Chang B-V, You CS. Weak ultrasonic pretreatment on anaerobic digestion of polyelectrolyte flocculated activated biosolids. Water Res 2002;36:2681-8.

[25] Lee DJ, Mueller JA. Preliminary treatments. In: Spinosa L, Vesilind PA, editors. Sludge into biosolids. UK: International Water Association, 2001. 